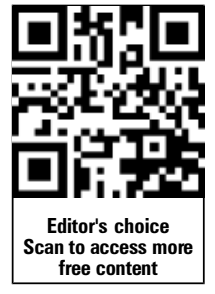

- Additional supplementary files are published online only. To view these files please visit the journal online (http://dx. doi.org/10.1136/heartjnl-2012302801).

${ }^{1}$ Department of Medicine and Geriatrics, Ruttonjee Hospital, Hong Kong, China ${ }^{2}$ Department of Medicine \& Therapeutics, the Chinese University of Hong Kong, Hong Kong, China

\section{Correspondence to} Dr Andrew Y W Li, Department of Medicine and Geriatrics, Ruttonjee Hospital, 266 Queen's Road East, Wan Chai, Hong Kong, China; liyw@ graduate.hku.hk

Accepted 9 October 2012 Published Online First 31 October 2012

\section{SLinked}

http://dx.doi.org/10.1136/ heartjnl-2012-303214

To cite: Li AYW, Ng F-H Chan FKL, et al. Heart 2013:99:468-473.

\title{
Effect of amlodipine on platelet inhibition by clopidogrel in patients with ischaemic heart disease: a randomised, controlled trial
}

\author{
Andrew Y W Li, ${ }^{1}$ Fook-Hong Ng, ${ }^{1}$ Francis K L Chan, ${ }^{2}$ Prabowo Tunggal, ${ }^{1}$ Kit Chan, \\ Yuk-Kong Lau ${ }^{1}$
}

ABSTRACT

Background Amlodipine inhibits cytochrome P450

(CYP) enzyme and has the potential to reduce clopidogrel bioactivation in vivo. Reports in previous retrospective studies described greater platelet reactivity in patients on amlodipine.

Objective To evaluate the treatment effect of clopidogrel in patients on amlodipine versus not on calcium-channel blockers (CCBs).

Design and setting Randomised, controlled, openlabel trial conducted in a regional acute hospital.

Patients and interventions 98 patients on clopidogrel for ischaemic heart disease were recruited consecutively and randomised to take either amlodipine or drugs with inert CYP effects as controls. The P2Y12 reaction unit (PRU) was measured using whole blood obtained at baseline and on day 28 .

Main outcome measures The primary analysis involved the PRU values on day 28 . The secondary analyses were percentage of platelet inhibition and poor response to clopidogrel as defined by PRU $>235$.

Results Both groups experienced comparable day 28 PRUs (amlodipine $227 \pm 84$ vs control 214 \pm 90 ; mean difference $12.7,95 \% \mathrm{Cl}-22$ to +47$)$. Percentage of platelet inhibition (amlodipine 33\% vs control 38\%, mean difference $-4.5 \%, 95 \% \mathrm{Cl}-14 \%$ to $+5 \%$ ) and those with poor response on day 28 (amlodipine 49\% vs control $45 \%$; $p=0.76$ ) did not differ significantly. Conclusions Concomitant amlodipine has no negative impact on clopidogrel-mediated platelet inhibition in patients with ischaemic heart disease.

\section{INTRODUCTION}

Amlodipine and clopidogrel are commonly co-administered in patients with ischaemic heart disease, because amlodipine is effective and relatively free from serious side effect in treating hypertension or angina. ${ }^{12}$

Clopidogrel is a prodrug requiring two-step metabolism by hepatic cytochrome P450 (CYP) to exert its antiplatelet effect. Clopidogrel is first converted to 2-oxo-clopidogrel (a thiolactone), then, in a second step, converted to the pharmacologically active thiol-containing metabolite.

The contribution of CYP1A2, CYP2B6 and CYP2C19 to the formation of 2-oxo-clopidogrel in the first step has been shown to be $35.8 \%, 19.4 \%$ and $44.9 \%$, respectively. The contribution of CYP2B6, CYP2C9, CYP2C19 and CYP3A4 to the formation of the active metabolite was $32.9 \%$, $6.8 \%, 20.6 \%$ and $39.8 \%$, respectively. ${ }^{3}$

The association between calcium channel blockers (CCBs) and decreased clopidogrel response is postulated to be related to the inhibition of CYP enzymes involved in clopidogrel bioactivation ${ }^{4}$; but this is controversial, with conflicting data. Some, ${ }^{5-7}$ but not all, ${ }^{8-10}$ previous observational studies have found that co-administration of CCBs was associated with a diminished pharmacodynamic response to clopidogrel.

In general, interindividual variability in cytochrome activity can be attributed to inactivation of the enzyme at the molecular level, or regulation of its transcription or polymorphism at the genetic level. ${ }^{11}$ Mechanisms of CYP enzyme inactivation can be further divided into three categories: reversible, quasi-irreversible and irreversible. Among CYP enzymes involved in clopidogrel metabolism, 3A4 and 2B6 may be inactivated by amlodipine in a quasi-irreversible mechanism. Amlodipine has relatively stronger inhibition on CYP2B6 and CYP1A1 but weak inhibition on other human CYP enzymes. ${ }^{12-14}$

However, pharmacokinetic studies suggest significant drug interaction is unlikely because the concentration of amlodipine required to produce a $50 \%$ decrease in the activities of CYP enzymes $\left(\mathrm{IC}_{50}\right)$ was found to be much greater than typical therapeutic concentrations of the drug in plasma.

The plasma concentration of amlodipine after a therapeutic dose has been reported to be $\sim 5-$ $50 \mathrm{nM} .{ }^{15}$ Considering that amlodipine exhibits an $\mathrm{IC}_{50}$ value of $4.9 \mu \mathrm{M}$ for CYP3A4 and $1.95 \mu \mathrm{M}$ for CYP2B6, these values were more than 100 -fold and 40 -fold, respectively, higher than its normal plasma concentration. ${ }^{13}$

We hypothesised that amlodipine has a minimal effect on clopidogrel metabolism. To measure the potential effect of amlodipine on clopidogrelmediated platelet inhibition, we quantified the P2Y12 reaction unit (PRU). ${ }^{3}$ It has been shown to correlate better with in vivo plasma levels of the active metabolite of clopidogrel than other point-of-care tests. ${ }^{16}$

Fibrinogen-coated microparticles in the VerifyNow assay agglutinate with platelets in whole blood in proportion to the number of expressed glycoprotein IIb/IIIa receptors. A change in optical transparency caused by higher P2Y12-mediated platelet reactivity is expressed by higher PRU. High on-treatment platelet reactivity has an increased 
risk of adverse cardiovascular events. ${ }^{16-22}$ A PRU value $>235$ correlated with a $6.3 \%$ absolute risk increase in non-fatal myocardial infarction at 1 year after PCI. ${ }^{23}$ The coefficient of variation for the test precision was less than $8 \% .^{24}$

The aim of this study is to evaluate the treatment effect of clopidogrel in patients on amlodipine versus not on CCBs using PRU as a surrogate outcome.

\section{METHODS}

\section{Study design}

This randomised, controlled, open-label trial was registered at clinicaltrial.gov (NCT01203696). The study complied with the Declaration of Helsinki and was approved by the local ethnics committees; all subjects gave written informed consent before enrolment.

\section{Study population and period}

Patients with ischaemic heart disease who were prescribed aspirin and clopidogrel co-therapy were screened at Ruttonjee Hospital between July 2010 and April 2011. The inclusion and exclusion criteria are listed in box 1 .

\section{Platelet reactivity measurement}

Patients had taken either a $300 \mathrm{mg}$ clopidogrel loading for at least $12 \mathrm{~h}$, or a maintenance dose of $75 \mathrm{mg}$ daily for at least 7 days before blood was sampled for baseline platelet reactivity, using the VerifyNow P2Y12 assay (Accumetrics, San Diego, California, USA). In case the patients had to undergo a

\section{Box 1 Selection criteria}

\section{Inclusion criteria}

Patients who fulfil all the following criteria would be eligible for study:

- Treated with aspirin and clopidogrel co-therapy for ischaemic heart disease

- Persistent angina greater than New York Heart Association (NYHA) II or blood pressure $>130 / 90 \mathrm{mmHg}$

- Asian ethnicity

- Informed consent obtained

Exclusion criteria

The presence of any of the followings excluded patients from the study:

- Use of any of the following drugs within 2 weeks:

- Any calcium-channel blockers

- Strong inhibitors of cytochrome P450 (CYP) 3A4 enzyme (any anti-HIV protease inhibitors, itraconazole, ketoconazole)

- Strong inducers of CYP 3A4 or 2B6 enzyme (carbamazepine, phenytoin, rifampicin, rifabutin, phenobarbital/primidone, St John's wort)

- Proton-pump inhibitors except pantoprazole

- Warfarin, non-steroidal anti-inflammatory drugs, phosphodiesterase inhibitors (cilostazol, dipyridamole)

- Use of heparin or glycoprotein Ilb/IIla inhibitor within 48 hours

- Platelet count $<150$ or $>400 \times 10^{9} / 1$

- Serum creatinine $>300 \mu \mathrm{mol} / \mathrm{l}$

- Active cancer

- Pregnant or lactating mothers percutaneous interventional procedure, blood was collected either before arterial puncture, or 1 week after the procedure, to avoid contamination by platelets activated during these procedures.

Venous blood was collected using $21 \mathrm{G}$ needles, in a one-off successful attempt in a vein which had not been previously punctured, according to the manufacturer's recommendations. The first $3 \mathrm{ml}$ of the blood drawn into a plain bottle was discarded to avoid contamination by platelets activated in this blood taking process; $2 \mathrm{ml}$ of blood was then collected using a citrate container for the P2Y12 assay. All blood samples were taken by the same operator, who also checked the machine for proper function daily.

\section{Randomisation}

All the treatment codes were prepared by an independent ward clerk at the beginning of the study and sealed in blinded envelopes for randomisation with equal allocation. The investigators drew a blinded envelope for each subject. After the first blood sampling, patients were randomised to either amlodipine (Norvasc, Pharmascience, Canada) or a non-calcium-CCB (non-CCB) with inert CYP activity as control. The dose of amlodipine was $2.5 \mathrm{mg}$ for patients whose baseline systolic blood pressure (SBP) was $131-140 \mathrm{~mm} \mathrm{Hg}$, and $2.5 \mathrm{mg}$ more for each increment of $10 \mathrm{~mm} \mathrm{Hg}$; maximum dose was $10 \mathrm{mg}$ for SBP $>161 \mathrm{~mm} \mathrm{Hg}$. The choice of non-CCB depended on the indication. For patients who needed additional drug for blood pressure control (defined as SBP $>130 \mathrm{~mm} \mathrm{Hg}$ or diastolic blood pressure (DBP) $>90 \mathrm{~mm} \mathrm{Hg}$ ), the choice of non-CCB would be either diuretics or hydralazine. Diuretic choices included indapamide (Natrilix SR, Sarbier, France), co-amilozide (Moduretic, Jean-marie-pharmacal, Hong Kong) or furosemide (Lasix, Aventis Pharma, Hong Kong). For patients requiring angina control, the non-CCB would be isosorbide mononitrate (Elantan, Schwarz Pharma, Hong Kong).

\section{Follow-up and primary analysis}

Clinical follow-up of patients and the second platelet reactivity were carried out on day $28 \pm 3$ at a designated outpatient clinic. Drug compliance was assessed by direct questioning and pill count. Telephone contacts were made by data coordinators when follow-ups were missed to enhance completeness of data.

The primary analysis was PRU at day 28. The secondary analyses were the percentage of P2Y12 receptor inhibition on day 28 , and the prevalence of poor response to clopidogrel on day 28 (defined as PRU $>235$, in line with the previously published consensus cut-off point). ${ }^{23}$

Patients with either acute coronary syndrome or stable coronary disease were enrolled. Primary outcomes of platelet reactivity were measured on day 28 to minimise the effect of acute coronary syndrome on platelet reactivity. This time frame, although arbitrary, was inferred from observational studies showing that high on-treatment platelet reactivity in the acute setting may settle later on when measured by optical aggregometry with ADP $20 \mu \mathrm{mol} / \mathrm{l}$ as the agonist, ${ }^{25}$ although this finding could not be reproduced by measurement with the VerifyNow assay. ${ }^{26}$ Furthermore, as coronary intervention performed after baseline blood sampling might induce endothelial injury and affect platelet reactivity, delaying the second measurement to day 28 would avoid this effect during hospitalisation.

\section{Statistical analysis}

Sample size was based on a previous cohort with similar selection criteria, showing a mean PRU difference of 48 between 
CCB and non-CCB group, with an SD of 84 units. $^{7}$ A total of 98 patients (49 per randomised group) was the minimum required with a power of $80 \%$ and two-sided $\alpha$ value of 0.05 , in order to reject the null hypothesis. Assuming 4\% dropout during the study, enrolment of 102 patients was expected.

Normal distribution of interval variables was verified by the Kolmogorov-Smirnov test. Continuous variables were expressed as mean $\pm \mathrm{SD}$ and compared with the unpaired two-tailored Student t-test. Comparisons of categorical variables, expressed as counts (percentage), were performed with the $\chi^{2}$ test or Fisher's exact test. Statistical analyses were performed using SPSS V.13.0 according to the intention-to-treat principle.

\section{RESULTS}

A total of 102 patients were enrolled consecutively. Among the 50 patients in the amlodipine group, one stopped clopidogrel after a normal angiogram refuted the diagnosis of ischaemic heart disease, and three patients among the 52 in the control group did not complete the study. None had crossover of treatment. The final study population consisted of 49 patients in each group (figure 1); $96 \%$ of the patients were Chinese.

The mean $\pm S D$ daily dose of amlodipine was $4.0 \mathrm{mg} \pm 2.4 \mathrm{mg}$. Drugs used as controls were hydralazine ( 8 patients, $65 \pm 22 \mathrm{mg}$ ), isosorbide mononitrate ( 18 patients, $48 \mathrm{mg} \pm 16 \mathrm{mg}$ ) and diuretics (23 patients). Drugs used in the diuretic group were: indapamide ( 8 patients, $1.5 \mathrm{mg}$ ), furosemide (7 patients, $22 \pm 7.5 \mathrm{mg}$ ) and co-amilozide ( 8 patients, $2.5 / 25 \mathrm{mg}$ ).
Baseline clinical characteristics and laboratory results of both groups were comparable (table 1). Normal distribution is observed at baseline and day 28 PRUs (Kolmogorov-Smirnov test, with $\mathrm{p}$ values ranging from 0.2 to 0.3 ). The baseline PRU was $206 \pm 82$ in the amlodipine group and $213 \pm 91$ in the control group (mean difference $7.0,95 \% \mathrm{CI}-41$ to +28 ). There was no significant difference in the percentage of P2Y12 receptor inhibition between the two treatment groups (amlodipine $38 \pm 23$, control $37 \pm 21$, mean difference $-1.0,95 \%$ CI -7 to $+10, \mathrm{p}=0.78)$. Mean SBP of both groups on day 28 was similar (amlodipine group $131 \pm 17 \mathrm{~mm} \mathrm{Hg}$, control group 129 $\pm 17 \mathrm{~mm} \mathrm{Hg}$, 95\% CI -1.6 to +12 ).

\section{Primary analysis}

The day 28 PRU was $227 \pm 84$ in the amlodipine group and $214 \pm 90$ in the control group (mean difference $12.7,95 \%$ CI -22 to 47 ); the means of the two groups did not differ significantly (table 2).

\section{Secondary analyses}

Percentage inhibition on day 28

The percentage inhibition on day 28 was $33 \% \pm 22 \%$ in the amlodipine group and $38 \% \pm 25 \%$ in the control group (mean difference $-4.5 \%, 95 \% \mathrm{CI}-14$ to $+5.0 \%)$.

Poor responders to clopidogrel on day 28

Twenty-four patients (49\%) in the amlodipine group and 22 $(45 \%)$ patients in the control group were classified as poor

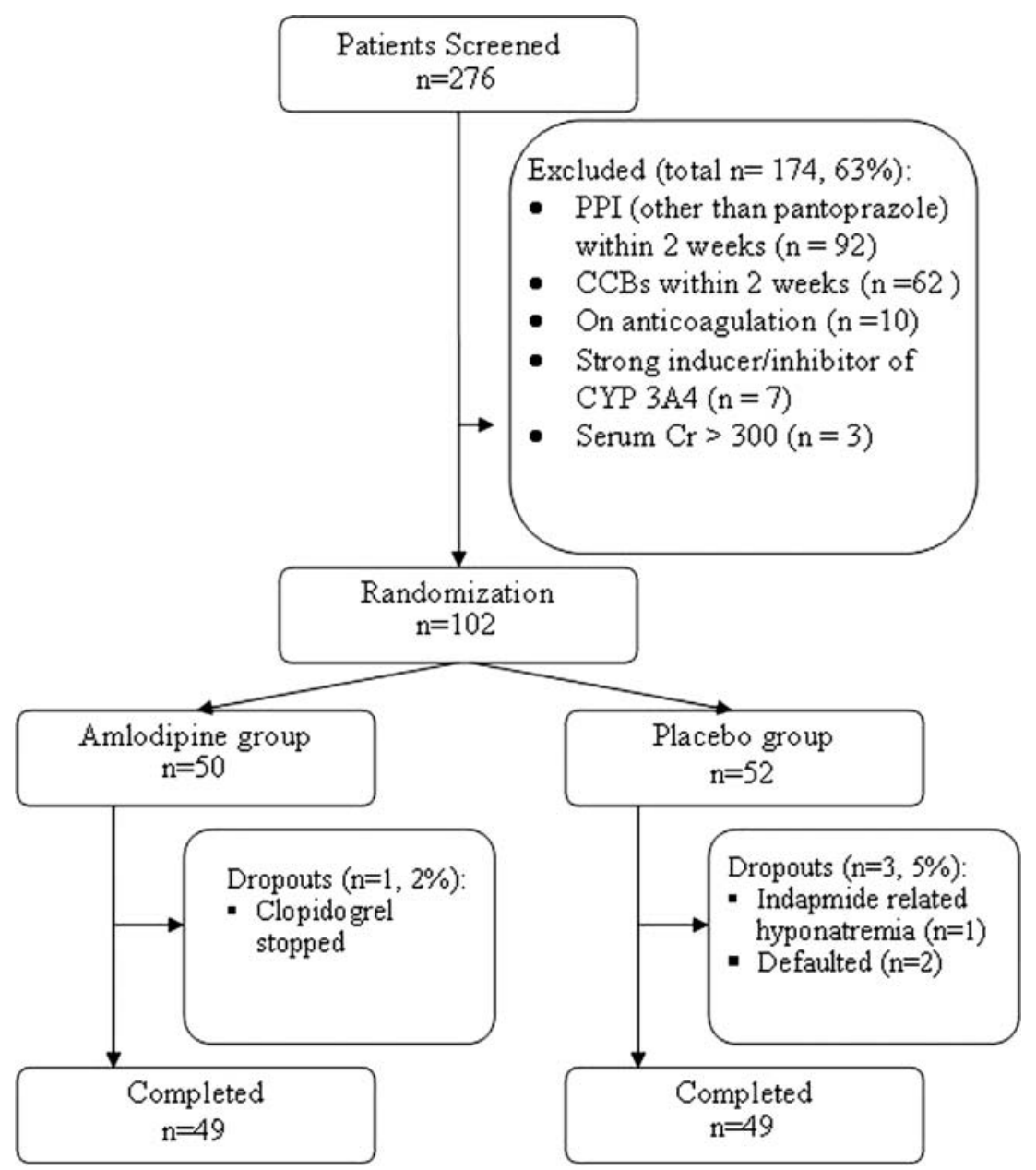

Figure 1 Study design. CCB, calcium-channel blocker; PPI, Proton pump inhibitor; $\mathrm{Cr}$, Creatinine (umol/l); 
Table 1 Baseline characteristics of patients

\begin{tabular}{|c|c|c|c|}
\hline & $\begin{array}{l}\text { Amlodipine } \\
\text { group }(n=49)\end{array}$ & $\begin{array}{l}\text { Control } \\
\text { group }(n=49)\end{array}$ & p Value \\
\hline Age in years $($ mean $\pm S D)$ & $69 \pm 10$ & $69 \pm 12$ & 0.87 \\
\hline Male sex, n (\%) & $31(\%)$ & $26(\%)$ & 0.31 \\
\hline \multicolumn{4}{|l|}{ Risk factors/history, n (\%) } \\
\hline Smoking & $2(4 \%)$ & $3(4 \%)$ & 0.64 \\
\hline Diabetes mellitus & $22(44 \%)$ & $27(55 \%)$ & 0.23 \\
\hline Hypertension & $48(98 \%)$ & $46(94 \%)$ & 0.31 \\
\hline $\begin{array}{l}\text { Previous myocardial } \\
\text { infarction* }\end{array}$ & $21(43 \%)$ & $26(53 \%)$ & 0.31 \\
\hline ACS within 1 montht & $22(45 \%)$ & $15(30 \%)$ & 0.15 \\
\hline \multicolumn{4}{|c|}{ Concomitant medications, $\mathrm{n}(\%)$} \\
\hline Pantoprazole & $30(61 \%)$ & $27(55 \%)$ & 0.53 \\
\hline ACE inhibitor & $33(67 \%)$ & $34(69 \%)$ & 0.83 \\
\hline $\begin{array}{l}\text { Angiotensin receptor } \\
\text { blocker }\end{array}$ & $10(20 \%)$ & $8(16 \%)$ & 0.60 \\
\hline$\beta$-blocker & $34(69 \%)$ & $35(71 \%)$ & 0.82 \\
\hline Spironolactone & $4(8 \%)$ & $4(8 \%)$ & 1.00 \\
\hline$\alpha$-blocker & $2(4 \%)$ & $6(12 \%)$ & 0.14 \\
\hline Digoxin & $0(0 \%)$ & $3(6 \%)$ & 0.08 \\
\hline Heparin $\ddagger$ & $5(10 \%)$ & $8(16 \%)$ & 0.37 \\
\hline $\begin{array}{l}\text { Cytochrome P450 3A4 } \\
\text { metabolising statin§ }\end{array}$ & $45(92 \%)$ & $44(90 \%)$ & 0.72 \\
\hline $\begin{array}{l}\text { Serotonin-selective } \\
\text { inhibitor }\end{array}$ & $0(0 \%)$ & $0(0 \%)$ & 1.00 \\
\hline Amiodarone & $0(0 \%)$ & $0(0 \%)$ & 1.00 \\
\hline Ginkgo biloba (herb) & $0(0 \%)$ & $0(0 \%)$ & 1.00 \\
\hline \multicolumn{4}{|c|}{ Laboratory data $($ mean $\pm S D)$} \\
\hline $\mathrm{Hb}, \mathrm{g} / \mathrm{dl}$ & $13 \pm 1.8$ & $13 \pm 2.0$ & 0.31 \\
\hline Platelets, $10^{9} / 1$ & $213 \pm 55$ & $208 \pm 54$ & 0.69 \\
\hline Creatinine, $\mu \mathrm{mol} / \mathrm{l}$ & $100 \pm 29$ & $98 \pm 29$ & 0.74 \\
\hline Bilirubin, $\mu \mathrm{mol} / / \mathrm{l}$ & $9 \pm 3.7$ & $11 \pm 6.0$ & 0.18 \\
\hline \multicolumn{4}{|c|}{ Baseline platelet reactivity at day $0(\operatorname{mean} \pm \mathrm{SD})$} \\
\hline P2Y12 reactivity unit & $206 \pm 82$ & $213 \pm 91$ & 0.72 \\
\hline Platelet inhibition, \% & $38 \pm 23$ & $37 \pm 21$ & 0.78 \\
\hline \multicolumn{4}{|c|}{$\begin{array}{l}\text { *Any history of myocardial infarction, defined as elevated troponin with either } \\
\text { ischaemic chest pain or ECG change. } \\
\text { tAcute coronary syndrome defined as Unstable angina, non-ST elevation or } \\
\text { ST-elevation myocardial infarction within } 1 \text { month before enrolment. } \\
\text { fHeparin used between } 7 \text { and } 2 \text { days before enrolment. } \\
\text { §Only simvastatin or atorvastatin used. }\end{array}$} \\
\hline
\end{tabular}

responders. Compared with baseline, when the corresponding numbers were $20(41 \%)$ and $16(33 \%)$, respectively, there was no significant difference in the numbers of poor responders $(p=0.76)$. No patient experienced death, myocardial infarction or heart failure requiring hospitalisation during the study period.

\section{DISCUSSION}

Our randomised study suggests that amlodipine does not attenuate the efficacy of clopidogrel, when compared with diuretics, hydralazine or nitrate as control. This result agrees with those from previous studies which indicated that interaction of amlodipine and clopidogrel via inhibition of cytochrome metabolism might be clinically insignificant. ${ }^{8-10}$ Although more potent antiplatelet agents such as prasugrel or ticagrelor are now available, a substantial proportion of the population is taking clopidogrel due to its cost. The absence of significant pharmacological interaction has economic and safety implications.

Several reports in the literature described CCBs as being associated with high on-treatment platelet reactivity. ${ }^{5-7}$ Harmsze et al, for example, conducted a cross-sectional study of 623 consecutive patients undergoing elective PCI, and reported that poor response to clopidogrel was 2.3 times more likely to occur in patients taking amlodipine than in those without CCB treatment. ${ }^{5}$ However, users of amlodipine were older than patients in the other groups in their population.

The strength of the current study is validation of similar baseline platelet reactivity in both groups before drug intervention. Moreover, known potential confounders, especially diabetes mellitus (DM), were balanced. The presence of DM was an independent predictor of lower platelet inhibition with clopidogrel. ${ }^{26}$ Insulin normally inhibits P2Y12 signalling on the platelet surface. Platelets in type $2 \mathrm{DM}$ patients were less responsive to insulin, thereby increasing signalling through the P2Y12 cascade. ${ }^{27-30}$ In addition, CYP2B6 enzyme is irreversibly inhibited by the active metabolite of amiodarone, and reversibly inhibited by the herbal compound ginkgo biloba. No patients in the current study reported use of these drugs.

Genetic variations leading to change in cytochrome activity may confound our primary outcome of PRU. ${ }^{31-34}$ The CYP2B6 gene has been mapped to chromosome 19. Exposure to drugs that induce CYP2B6 transcription through nuclear receptors will increase the enzyme activity and hence may neutralise the inhibitory effect of amlodipine. ${ }^{35}$ Examples of these drugs include phenobarbitone, phenytoin, carbamazepine and rifampicin. Nonetheless, patients on these drugs were excluded from our study. Because of some common mechanism of transcription regulation shared between CYP2B6 and 3A4, a number of drugs can induce transcription of both genes simultaneously. ${ }^{36-38}$

Although tests on genetic polymorphism were not performed in our study, its inter-ethnic difference was minimised because our population only consisted of ethnic Asians. Single nucleotide polymorphisms of CYP2B6 have been reported. The most frequent variant allele is $* 6$ caused by $516 \mathrm{G}>\mathrm{T}$ and $785 \mathrm{~A}>\mathrm{G} .{ }^{39}$ Patients with homozygous $(* 6 / * 6)$ genotype were reported to have $50 \%$ reduction in the mean enzyme activity compared with the wild-type $(* 1 / * 1)$ group. ${ }^{40}$ However, the prevalence of the CYP2B $6 * 6 / * 6$ genotype is reported to be only $2-5 \%$ in Chinese. ${ }^{41}$ As CYP2B6 only plays a minor role in clopidogrel bioactivation, it can therefore be expected that polymorphism of CYP2B6 will have only a modest effect on PRU in our patients. Recent findings that carriage of loss of function *2 allele of CYP2C19 gene only accounts for 5\% of the variability

Table 2 Results of analysis on day 28

\begin{tabular}{|c|c|c|c|c|}
\hline & $\begin{array}{l}\text { Amlodipine group } \\
\text { (mean } \pm \text { SD) }\end{array}$ & $\begin{array}{l}\text { Control group } \\
\text { (mean } \pm \text { SD) }\end{array}$ & $\begin{array}{l}\text { Mean difference } \\
(95 \% \mathrm{CI})\end{array}$ & p Value \\
\hline Platelet reactivity unit (primary end-point) & $227 \pm 84$ & $214 \pm 90$ & $12.7(-22$ to +47$)$ & 0.47 \\
\hline Platelet inhibition, \% (secondary end-point) & $33 \pm 22$ & $38 \pm 25$ & $-4.5(-14$ to +5.0$)$ & 0.34 \\
\hline No. of poor responder to clopidogrel, $\mathrm{n}$ (\%) (secondary end-point) & $24(49 \%)$ & $22(45 \%)$ & - & 0.76 \\
\hline
\end{tabular}


of the pharmacodynamic response to clopidogrel are also consistent in this regard. ${ }^{42}$

This study had several limitations. First, it was not placebo controlled, thus the control treatment might have influenced platelet inhibition. However, this design resembled the real-life situation as diuretics and nitrates were the commonest alternatives to CCBs in that context. Second, the study sample size was relatively small in view of the inherent large variability of on-treatment platelet reactivity. Surrogate pharmacological endpoints, albeit with clinical implications, were investigated instead of clinical adverse cardiovascular events. Our results are hypothesis-generating but open to the possibility of chance findings. Third, the dose of amlodipine was modest and further studies to confirm a similar effect for higher doses of amlodipine would be helpful. The current result should not be generalised to other subclasses of CCBs because of different pharmacodynamic properties. ${ }^{12} 43$

In conclusion, amlodipine does not significantly attenuate the antiplatelet effect of clopidogrel in patients with ischaemic heart disease with respect to pharmacological end-points. The common practice of concomitant use of these two drugs may be continued.

Contributors All authors were solely responsible for the design, conduct and analyses of the study, drafting and editing of the paper and its final contents.

Funding This study was sponsored by the Cardiac Research Fund, Ruttonjee Hospital, which provided the expenditure for the platelet reactivity assay.

Competing interest FKLC has served as a consultant for Pfizer, Eisai, Takeda and Otsuka, and has received lecture fees from Pfizer, Astra Zeneca and Takeda.

Patient consent Obtained.

Ethics approval Ethics Committee of the Hong Kong East Cluster, Hospital Authority, Hong Kong Special Administrative Region.

Provenance and peer review Not commissioned; externally peer reviewed.

\section{REFERENCES}

1 O'Connor CM, Carson PE, Miller AB. Effect of amlodipine on mode of death among patients with advanced heart failure in the PRAISE trial. prospective Randomized Amlodipine Survival Evaluation. Am J Cardiol 1998:82:881-7.

2 Elkayam U, Amin J, Mehra A, et al. A prospective, randomized, double-blind, crossover study to compare the efficacy and safety of chronic nifedipine therapy with that of isosorbide dinitrate and their combination in the treatment of chronic congestive heart failure. Circulation 1990;82:1954-61.

3 Kazui M, Nishiya $Y$, Ishizuka T, et al. Identification of the human cytochrome P450 enzymes involved in the two oxidative steps in the bioactivation of clopidogrel to its pharmacologically active metabolite. Drug Metab Dispos 2010;38:92-9.

4 Siller-Matula J, Schror K, Wojta J, et al. Thienopyridines in cardiovascular disease: focus on clopidogrel resistance. Thromb Haemost 2007;97:385-93.

5 Harmsze AM, Robijns K, van Werkum JW, et al. The use of amlodipine, but not of P-glycoprotein inhibiting calcium channel blockers is associated with clopidogrel poor-response. Thromb Haemost 2010;103:920-5.

6 Siller-Matula JM, Lang I, Christ G, et al. Calcium-channel blockers reduce the antiplatelet effect of clopidogrel. J Am Coll Cardiol 2008;52:1557-63.

7 Gremmel T, Steiner S, Seidinger D, et al. Calcium-channel blockers decrease clopidogrel-mediated platelet inhibition. Heart 2010;96:186-9.

8 Sarafoff N, Neumann L, Morath T, et al. Lack of impact of calcium-channel blockers on the pharmacodynamic effect and the clinical efficacy of clopidogrel after drug-eluting stenting. Am Heart J 2011;161:605-10.

9 Olesen JB, Gislason GH, Charlot MG, et al. Calcium-channel blockers do not alter the clinical efficacy of clopidogrel after myocardial infarction: a nationwide cohort study. J Am Coll Cardiol 2011:57:409-17.

10 Good CW, Steinhubl SR, Brennan DM, et al. Is there a clinically significant interaction between calcium channel antagonists and clopidogrel?: results from the Clopidogrel for the Reduction of Events During Observation (CREDO) trial. Circ Cardiovasc Interv 2012;5:77-81.

11 Lin JH, Lu AYH. Inhibition and induction of cytochrome P450 and the clinical implications. Clin Pharmacokinet 1998;35:361-90.

12 Katoh M, Nakajima M, Shimada N, et al. Inhibition of human cytochrome P450 enzymes by 1,4-dihydropyridine calcium antagonists: prediction of in vivo drug-drug interactions. Eur J Clin Pharmacol 2000:55:843-52.
13 Ma B, Prueksaritanont T, Lin JH. Drug interactions with calcium channel blockers: possible involvement of metabolite-intermediate complexation with CYP3A. Drug Metab Dispos 2000;28:125-30.

14 Zhou SF, Xue CC, Yu XQ, et al. Clinically important drug interactions potentially involving mechanism-based inhibition of cytochrome P450 3A4 and the role of therapeutic drug monitoring. Ther Drug Monit 2007;29:687-710.

15 Kelly JG, O'Malley K. Clinical pharmacokinetics of calcium antagonists: An update. Clin Pharmacokinet 1992;22:416-33.

16 Bouman HJ, Parlak E, van Werkum JW, et al. Which platelet function test is suitable to monitor clopidogrel responsiveness? A pharmacokinetic analysis on the active metabolite of clopidogrel. J Thromb Haemost 2010;8:482-8.

17 Bonello L, Tantry US, Marcucci $\mathrm{R}$, et al. Consensus and future directions on the definition of high on-treatment platelet reactivity to adenosine diphosphate. J Am Coll Cardiol 2010;56:919-33.

18 Sibbing D, Byrne RA, Bernlochner I, et al. High platelet reactivity and clinical outcome- fact and fiction. Thromb Haemost 2011;106:191-202.

19 Marcucci R, Gori AM, Paniccia R, et al. Cardiovascular death and nonfatal myocardial infarction in acute coronary syndrome patients receiving coronary stenting are predicted by residual platelet reactivity to ADP detected by a point-of-care assay: a 12-month follow-up. Circulation 2009;119: 237-42.

20 Cuisset T, Hamilos M, Sarma J, et al. Relation of low response to clopidogrel assessed with point-of-care assay to periprocedural myonecrosis in patients undergoing elective coronary stenting for stable angina pectoris. Am J Cardiol 2008:101:1700-3.

21 Valgimigli M, Campo G, de Cesare N, et al. Tailoring Treatment With Tirofiban in Patients Showing Resistance to Aspirin and/or Resistance to Clopidogrel (3T/2R) Investigators. Intensifying platelet inhibition with tirofiban in poor responders to aspirin, clopidogrel, or both agents undergoing elective coronary intervention: results from the double-blind, prospective, randomized Tailoring Treatment with Tirofiban in Patients Showing Resistance to Aspirin and/or Resistance to Clopidogrel study. Circulation 2009:119:3215-22.

22 Patti G, Nusca A, Mangiacapra F, et al. Point-of-care measurement of clopidogrel responsiveness predicts clinical outcome in patients undergoing percutaneous coronary intervention results of the ARMYDA-PRO (Antiplatelet therapy for Reduction of MYocardial Damage during Angioplasty-Platelet Reactivity Predicts Outcome) study. J Am Coll Cardiol 2008;52:1128-33.

23 Breet NJ, Van Werkum JW, Bouman HJ, et al. Comparison of platelet function tests in predicting clinical outcome in patients undergoing coronary stent implantation. JAMA 2010;303:754-62.

24 Malinin A, Pokov A, Swaim L, et al. Validation of a verifynow-P2Y12 cartridge for monitoring platelet inhibition with clopidogrel. Methods Find Exp Clin Pharmaco 2006:28:315-22

25 Geisler T, Kapp M, Gohring-Frischholz K, et al. Residual platelet activity is increased in clopidogrel- and ASA-treated patients with coronary stenting for acute coronary syndromes compared with stable coronary artery disease. Heart 2008;94: 743-7.

26 Ang L, Palakodeti V, Khalid A, et al. Elevated plasma fibrinogen and diabetes mellitus are associated with lower inhibition of platelet reactivity with clopidogrel. J Am Coll Cardiol 2008:52:1052-9.

27 Angiolillo DJ, Bernardo E, Ramirez C, et al. Insulin therapy is associated with platelet dysfunction in patients with type 2 diabetes mellitus on dual ora antiplatelet treatment. J Am Coll Cardiol 2006;48:298-304.

28 Carr ME. Diabetes mellitus: a hypercoagulable state. J Diabetes Complications 2001;15:44-54

29 Ferriera IA, Mocking Al, Feijge MA, et al. Platelet inhibition by insulin is absent in type 2 diabetes mellitus. Arterioscler Thromb Vasc Biol 2006;26:417-22.

30 Winocour PD, Watala C, Perry DW, et al. Decreased platelet membrane fluidity due to glycation or acetylation of membrane proteins. Thromb Haemost 1992;68:577-82

31 Mega JL, Close SL, Wiviott SD, et al. Cytochrome P-450 polymorphisms and response to clopidogrel. N Engl J Med 2009;360:354-62.

32 Sibbing $D$, Braun $S$, Morath $T$, et al. Platelet reactivity after clopidogrel treatment assessed with point-of-care analysis and early drug-eluting stent thrombosis. J Am Coll Cardiol 2009:53:849-56.

33 Desta Z, Zhao X, Shin JG, et al. Clinical significance of the cytochrome P450 2C19 genetic polymorphism. Clin Pharmacokinet 2002;41:913-58.

34 Food and Drug Administration. Reduced effectiveness of Plavix (clopidogrel) in patients who are poor metabolizers of the drug. FDA drug safety communication. http://www.fda.gov/Drugs/DrugSafety/ PostmarketDrugSafetylnformationforPatientsandProviders/ucm203888.htm.

35 Wang H, Tompkins LM. CYP2B6: new insights into a historically overlooked cytochrome P450 isozyme. Curr Drug Metab 2008;9:598-610.

36 Geick A, Eichelbaum M, Burk 0. Nuclear receptor response elements mediate induction of intestinal MDR1 by rifampin. J Biol Chem 2001;276:14581-7.

37 Wang $H$, Faucette SR, Gilbert D, et al. Glucocorticoid receptor enhancement of pregnane $\mathrm{X}$ receptor-mediated $\mathrm{CYP} 2 \mathrm{~B} 6$ regulation in primary human hepatocytes. Drug Metab Dispos 2003;31:620-30. 
38 Ferguson SS, LeCluyse EL, Negishi M, et al. Regulation of human CYP2C9 by the constitutive androstane receptor: discovery of a new distal binding site. Mol Pharmacol 2002:62:737-46.

39 Mehlotra RK, Ziats MN, Bockarie MJ, et al. Prevalence of CYP2B6 alleles in malaria-endemic populations of West Africa and Papua New Guinea. Eur J Clin Pharmacol 2006;62:267-75.

40 Lang T, Klein K, Fischer J, et al. Extensive genetic polymorphism in the human CYP2B6 gene with impact on expression and function in human liver. Pharmacogenetics 2001;11:399-415.
41 Guan S, Huang M, Li X, et al. Intra- and inter-ethnic differences in the allele frequencies of cytochrome P450 2B6 gene in Chinese. Pharm Res 2006;23:1983-90.

42 Bouman HJ, Harmsze AM, van Werkum JW, et al. Variability in on-treatment platelet reactivity explained by CYP2C $19^{*} 2$ genotype is modest in clopidogrel pretreated patients undergoing coronary stenting. Heart 2011;97:1239-44.

43 Guengerich FP, Peterson LA, Böcker RH. Cytochrome P-450-catalyzed hydroxylation and carboxylic acid ester cleavage of hantzsch pyridine esters. I Biol Chem 1988;263:8176-83. 